\title{
STANDARDS DATABASE MAINTENANCE PHASE II
}

Submitted to:

Mr. William G. Becker, NSRP Program Manager NEWPORT NEWS SHIPBUILDING COMPANY 4101 Washington Avenue

Newport News, Virginia 23607

September 9, 1997

Principal Investigators:

Albert W. Horsmon, Jr.

Scott B. Clapham

Marine Systems Division

Transportation Research Institute

The University of Michigan

Ann Arbor, Michigan 48109-2150 
Technical Report Documentation Page

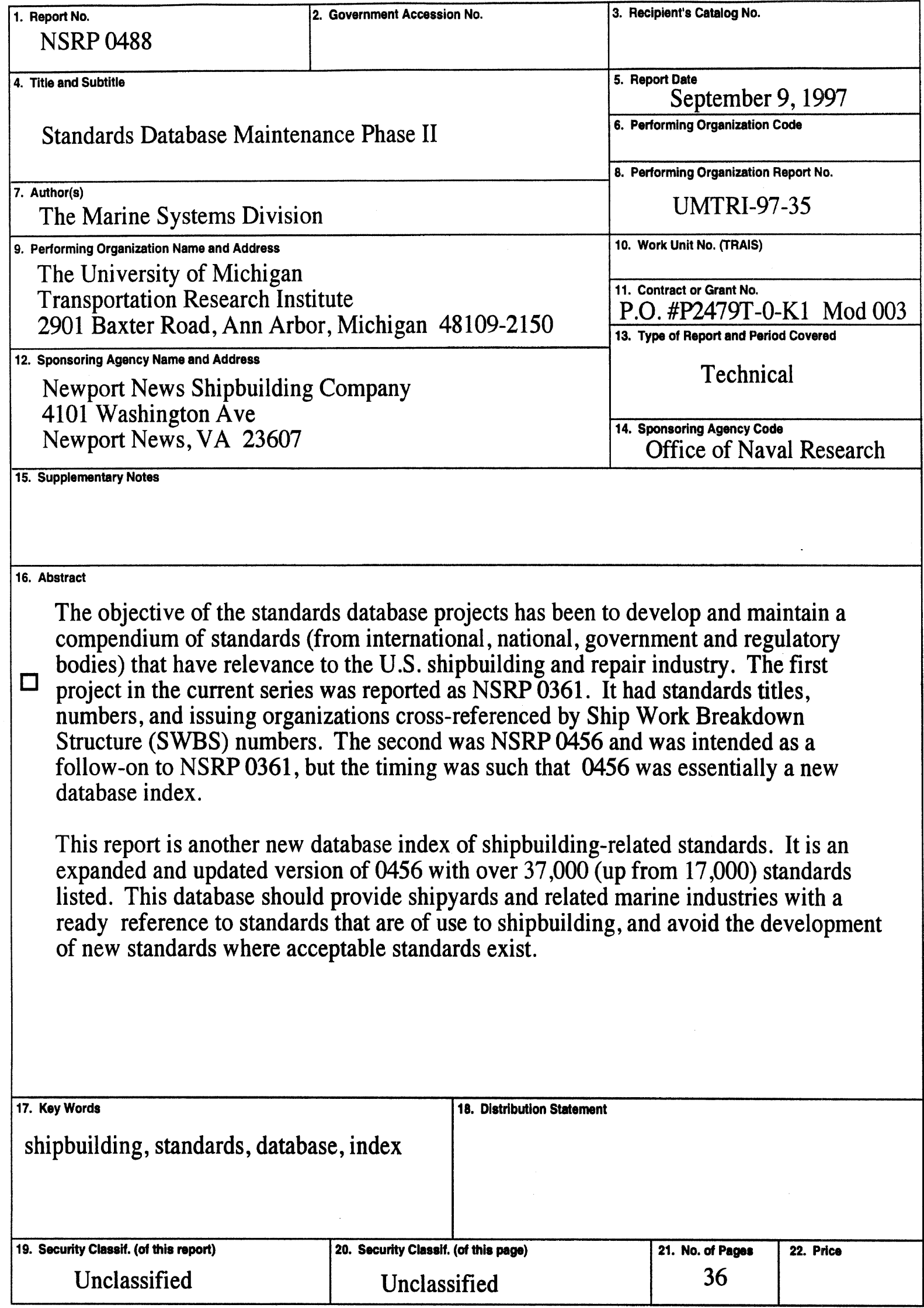


The objective of the standards database projects has been to develop and maintain a compendium of standards (from international, national, military, and regulatory bodies) that have relevance to the U.S. shipbuilding, repair and related industries. The first compendium in the current series was reported as NSRP 0361 and accomplished to replace an older database (NSRP 0088) that was available only in printed form. It has standards titles, numbers, and issuing organizations cross-referenced by Ship Work Breakdown Structure (SWBS) numbers and contains about 10,400 titles. It is still available on a single 3.5 inch floppy disk but has been superseded by the current report. The second compendium was NSRP 0456 and was intended as a follow-on to NSRP 0361 , but the timing was such that 0456 was essentially a new database index with 17,000 standards. It is still available on two (2) 3.5 inch floppy disk but has also been superseded by the current report

This Phase II (contractually Phase II of the same contract that produced report NSRP 0456) is a new database index of shipbuilding related standards. It is an expanded and updated version of 0456 with over 37,000 standards indexed and cross-referenced by SWBS numbers. This database should provide shipyards and related marine industries with a ready reference to standards that are of use to shipbuilding, and avoid the development of new standards where acceptable standards exist

The database is accessible directly from the World Wide Web at:

http://www.umich.edu/ umtrimsd/docctr/edocs/index.htm

and can be downloaded and installed on a personal computer of reasonable capacity (486/66 minimum) that runs Microsoft Windows $95^{\circledR}$ or Windows $\mathrm{NT}^{\oplus}$. It is basically a Microsoft ACCESS $^{\otimes}$ database packaged with a stand alone search engine. It can also be loaded into the Microsoft ACCESS ${ }^{\circledR}$ software and searched through that program. 


\section{STANDARDS DATABASE MAINTENANCE PHASE II}

\section{TABLE OF CONTENTS}

Report Documentation Page ............................................ i

Executive Summary .......................................................ii

Table of Contents............................................................. ii

Introduction and Background .......................................... 1

Getting to the Database ................................................. 2

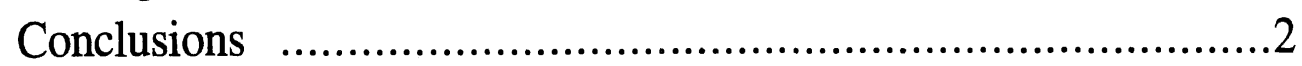

\section{Appendices}
A. Installation and Usage Instructions
A-1
B. SWBS Numbers
B-1
C. Organizations and Acronyms.
C-1
D. Sample Printouts
D-1 


\section{INTRODUCTION and BACKGROUND}

This report is a product of a program directed by the National Shipbuilding Research Program (NSRP) and the Ship Production Committee (SPC) of the Society of Naval Architects and Marine Engineers (SNAME). Newport News Shipbuilding was the prime contractor, with the University of Michigan Transportation Research Institute (UMTRI) working under a subcontract.

Under the SPC Panel SP-6 proposal, the technical objective of this project is to maintain and expand a compendium of standards (international, national, military, and regulatory) that have relevance to the U.S. shipbuilding and repair industry. The intended benefits are to provide shipyards with a ready reference to standards that are of use to shipbuilding and to eliminate the need for development of new standards where acceptable standards exist.

The project was performed at UMTRI by Albert W. Horsmon, Jr. and Scott B. Clapham. Thomas Lamb was project director.

Standards are a key element in the efficient design, construction, and repair of ships and vessels in all shipyards. As a result, there is a continuous need by many designers, engineers, managers, and other people associated with marine work to reference standards from a wide range of regulatory bodies, government agencies, technical societies, and private industry groups. For this database, standards include:

- Consensus standards, such as those developed by the American Society of Testing and Materials (ASTM),

- Government regulations and requirements, such as U.S. Coast Guard regulations,

- Military Specifications (MilSpecs), and

- Related rules requirements.

Traditional methods of locating standards center around referencing many documents and books of standards issued by diverse individual organizations. Copies of the standards on microfiche may have reduced the volume of the references but not the difficulty in searching for information. Computerized versions of the standards made searches faster, but frequently gave users more information than they needed for initial investigations. This can be not only time consuming, but may result in either not finding a standard or developing a new standard where a suitable one may already exist.

The first shipbuilding standards compendium for the NSRP was completed as NSRP 0088 in September of 1979 under an NSRP Project titled "A Compendium of Shipbuilding Standards." It was produced as a hard copy database with 2,580 entries, predominately from domestic agencies. It was issued in hard copy format sorted by four methods, but without provision for maintenance. In a short period of time it was outdated.

As a result, the Marine Industry Standards Panel (SP-6) of the Ship Production Committee of SNAME identified the need for a computerized compendium of standards pertinent to shipbuilding and ship repair. The first project in the current series was reported as NSRP 0361 in 1992. It has standards titles, numbers, and issuing organizations cross-referenced by Ship Work Breakdown Structure $\left(\mathrm{SWBS}^{1}\right)$ numbers. It contains about 10,400 titles from 50 organizations, both domestic and international. The database was supplied compressed on a single floppy disk as a Borland

\footnotetext{
${ }^{1}$ SWBS - Ship Work Breakdown Structure. A systems-oriented coding structure used by the U.S. Navy to classify components from design through the life of the ship. A listing is provided in the Appendix.
} 
dBASE IV ${ }^{\circledR}$ file, overcoming some of the limitations of the earlier project. It is still available on a single 3.5 inch floppy disk but has been superseded by the current report.

As standards changed, the NSRP 0361 database became somewhat outdated. The SP-6 Panel recognized the need for maintenance of this (NSRP 0361) database and planned a follow-on maintenance project, but the follow-on project was not funded until nearly two years later. The maintenance project was planned as a two year project. NSRP 0456 (the Phase I report) was intended as the follow-on to NSRP 0361, but the timing was such that NSRP 0456 was essentially a new database index with 17,000 standards. NSRP 0456 is supplied compressed onto two floppy disks in a number of different database formats as requested by subscribers. However, it has also been superseded by the current report

This report completes Phase II of the maintenance project and is an expanded and updated version of the NSRP 0456 database, with over 37,000 standards indexed and cross-referenced by SWBS numbers. The database is available directly from the World Wide Web and can be downloaded and installed on a personal computer of reasonable capacity. A minimum of a 486/66 machine with $16 \mathrm{M}$ of RAM should be used to look at the database. It is basically a Microsoft ACCESS $^{\circledast}$ database packaged with a stand alone search engine.

\section{GETTING TO THE DATABASE}

To access the Phase II Standards Database for Windows 95 and NT machines, on the World Wide Web go to:

http://www.umich.edu/ umtrimsd/docctr/edocs/index.htm

Once there click on NSRP Report 0488 - it will download the zipped file to your desktop. These instructions or updates to them are also located there.

To access the Standards Database through an FTP server go to the FTP site:

\subsubsection{6}

Log in as "anonymous," use your email address as the password. Once into the site, open the folders "doccen" and in doccen open "reports." In the reports folder download the one titled DBinstal.zip to your desktop.

On your desktop, double click the DBinstal.zip folder and your host unzip program will unzip the files into the specified folder. In the unzipped group of files, find and double click the "setup.exe" file and it will create a StandardsDB folder on your C drive. After the files are installed, Double Click the Standards.exe file in the StandardsDB folder and you should be ready to search.

More complete instructions, including special search instructions, are in Appendix A. Appendix B is a listing of SWBS numbers and titles. Appendix C is a listing of the organizations whose standards are listed in the database and the acronyms used to identify them. Appendix D has sample printouts from the database

\section{CONCLUSIONS}

The Phase II standards database is an easy to use comprehensive index of marine related standards that should give the user a good first cut at finding which standards are applicable to a specific subject. 


\section{Appendix A}

\section{Installation and Usage Instructions}




\section{OBTAINING THE DATABASE}

To access the Phase II Standards Database for Windows 95 and NT machines, on the World Wide Web go to:

$$
\text { http://www.umich.edu/ umtrimsd/docctr/edocs/index.htm }
$$

Once there click on NSRP Report 0488 - it will download the zipped file to your desktop. These instructions or updates to them are also located there.

To access the Standards Database through an FTP server go to the FTP site:

$$
\text { 141.211.187.96 }
$$

Log in as "anonymous," use your email address as the password. Once into the site, open the folders "doccen" and in doccen open "reports." In the reports folder download the one titled DBinstal.zip to your desktop.

To obtain some other form of the database, contact UMTRI directly or by email at seai@umich.edu.

\section{INSTALLATION}

Run the installation program, "Setup.exe." The program must be installed in the directory C: StandardsDB." The setup program will install a number of files on the computer. Dynamic Link Libraries (DLLs) will be placed in your Windows directory. The executable file, "StandardsDB.Exe," will be placed in C: Standards, and the database of standards, DB2.Mdb, will be placed in C: StandardsDB

\section{USAGE}

\section{Without the Search Utility}

The standards database, DB2.Mdb, is a Microsoft ACCESS 7. $0^{\circledR}$ database. It can be opened and modified like any other ACCESS database. It may also be opened in any other compatible database program.

\section{With the Search Utility}

The Search Utility that has been included with the database allows users to search by any combination of criteria, and view and print the results in three different formats.

There are four different titled criteria that can be used for searching: SWBS number, entering a keyword in the "Title" box, "Originating Organization," and "Standard Number." To search by a criterion, the corresponding box on the left must be checked and a search criterion entered. The search criterion may be an exact entry, such as for the SWBS field " 120 ," or it may include wildcard characters such as *, ?, and \#. The most powerful wildcard operator is the *. To search for all standards with the word "pipe" anywhere in their title the following (without quote marks) would be entered into the box to the right of the keyword, "*pipe*." Examples of the other more restrictive operators are given below. 


\begin{tabular}{|l|l|l|l|}
\hline Kind of match & Pattern & Match & No Match \\
\hline Multiple characters & "a*a" & "aa", "aBa", "aBBBa" & "aBC" \\
\hline & "*ab*" & "abc", "AABB", "Xab" & "aZb", "bac" \\
\hline Special character & "a[*]a" & "a*a" & "aaa" \\
\hline Multiple characters & "ab*" & "abcdefg", "abc" & "cab", "aab" \\
\hline Single character & "a?a" & "aaa", "a3a", "aBa" & "aBBBa" \\
\hline Single digit & "a\#a" & "a0a", "a1a", "a2a" & "aa", "a10a" \\
\hline Range of characters & "[a-z]" & "f", "p", "j" & "2", "\&" \\
\hline Outside a range & "[!a-z]" & "9", "\&", "\%" & "b", "a" \\
\hline Not a digit & "[!0-9]" & "A", "a", "\&", " & "0", "1", "9" \\
\hline Combined & "a[!b-m]\#" & "An9", "az0", "a99" & "abc", "aj0" \\
\hline
\end{tabular}

The abbreviation for the organization search criterion may be entered manually or selected from the drop down list. Once a search has been completed the number of matches is displayed on the right side of the screen. The user may then view the results ordered by Standard Number, Organization, or SWBS by clicking on the appropriate radio button and clicking the "View Results" button. The results will be displayed in a new window. This window can be printed by clicking on the printer icon. The results can be paged through by clicking on the arrows. The view can be zoomed in and out by clicking on the magnifying glass icon. When the user has finished viewing the results the "Close" button should be pressed and the Search Utility will be displayed.

The Search Utility also allows the user to search the results of a previous query. This allows more than one keyword to be used. To search the results of the last query for additional criteria, select the "Search Previous" option, enter the new criterion, and click the "Search Database" button.

\section{MAINTAINING THE DATABASE}

Users who would like to add additional standards to the database may do so using Microsoft Access 7.0. The Standards Database is entitled DB2.Mdb. Any number of records may be added or deleted and the field entries modified. However, the layout of the table must remain the same and the field names must not be changed. 


\section{Appendix B}

\section{SWBS Numbers}




\section{SHIP WORK BREAKDOWN STRUCTURE TITLES}

Group 0-99 General Guidance and Administration

000 General Guidance and Administration

010 Combat Capabilities (Offensive and Defensive)

011 Air Weapons Vs. Air Targets

$012 \quad$ Air Weapons Vs. Surface Targets

013

Air Weapons Vs. Underwater Targets

014

Surface Weapons Vs. Air Targets

015

Surface Weapons Vs. Surface Targets

016

Surface Weapons Vs. Underwater Targets

017

Underwater Weapons Vs. Surface Targets

018

Underwater Weapons Vs. Underwater Targets

020

021

Strategic and Special Capabilities

022

Underwater Based Deterrents

023

Amphibious Warfare

024

Mine and Mine Countermeasure Warfare

025

030

031

Inshore Warfare

032

Tactical and Strategic Oper. Support Capabilities

Command/Control/Communications

033

Surveillance/Reconnaissance/Intelligence

034

Electronic Warfare and Nuc/Bio/Chemical Defense

035

Logistics/Sealift

040

Other Support

041

042

Ship System Management

043

Project Management

044

General Administrative Requirements

050

Life Cycle Costing

Ship Operation

051

052

053

Ship System Performance

054

Ship System Performance Concepts

Ship Subsystem Performance Concepts

060

Selected Concepts

Subsystem Characteristics

061 Hull Structure

062 Propulsion Plant

063 Electric Plant

064 Command and Surveillance

065 Auxiliary Systems

$066 \quad$ Outfitting

067 Weapons

068 Integration and Engineering 
SHIP WORK BREAKDOWN STRUCTURE TITLES

Ship Assembly

070

071

General Requirements for Design and Construction

072

Access

073

Shock

074

Noise and Vibration

075

Casting, Welding, Riveting, Allied Processes (General)

076 Threaded Fasteners Standards

077

Reliability ad Maintainability

078

Safety

079

Materials

080

081

Seaworthiness

082

083

Integrated Logistic Support Requirements

Maintenance

084

Support and Test Equipment

Supply Support

085

Transportation and Handling

086

Engineering Drawings

087

Technical Manuals and Other Data

088

089

090

091

092

093

Facilities

Personnel and Training

Training Equipment

Quality Assurance Requirements

Ship Inspections

094

095

096

Ship Tests

Combat Systems Checkout

097

098

099

Regular Ship Trials

Whole Ship Testing

Weight Control

Inclining Experiment and Trim Dive

Models and Mockups

Photographs

\section{Group 1 Hull Structure}

Hull Structure, General 


\section{SHIP WORK BREAKDOWN STRUCTURE TITLES}

Longit. Framing, Surf. Ship and Submarine Press. Hull Transv. Framing, Surf. Ship and Submarine Press. Hull Longit. and Transv. Submarine Non-press. Hull Framing Lift System Flexible Skirts and Seals

Hull Structural Bulkheads

Longitudinal Structural Bulkheads

Transverse Structural Bulkheads

Trunks and Enclosures

Bulkheads in Torpedo Protection System

Submarine Hard Tanks

Submarine Soft Tanks

Hull Decks

Main Deck

2nd Deck

3rd Deck

4th Deck

5th Deck and Decks Below

01 Hull Deck (Forecastle and Poop Decks)

02 Hull Deck

03 Hull Deck

04 Hull Deck and Hull Decks Above

Hull Platforms and Flats

1st Platform

2nd Platform

3rd Platform

4th Platform

5th Platform

Flats

Deck House Structure

Deckhouse Structure to First Level

1st Deckhouse Level

2nd Deckhouse Level

3rd Deckhouse Level

4th Deckhouse Level

5th Deckhouse Level

6th Deckhouse Level

7th Deckhouse Level

8th Deckhouse Level and Above

Special Structures

Structural Castings, Forgings, and Equiv. Weldments

Stacks and Macks (Combined Stack and Mast)

Sea Chests

Ballistic Plating 
Sonar Domes

166 Sponsons

Hull Structural Closures

Deckhouse Structural Closures Masts, Kingposts, and Service platforms

171 Masts, Towers, Tetrapods Kingposts and Support Frames Service Platforms Foundations Hull Structure Foundations Propulsion Plant Foundations Electric Plant Foundations Command and Surveillance Foundations Auxiliary Systems Foundations Outfit and Furnishings Foundations Armament Foundations Special Purpose Systems

\section{Group 2 Propulsion Plant}

Propulsion Plant, General

202 Energy Generating System (Nuclear)

Nuclear Steam Generator

Reactors

Reactor Coolant System

Reactor Coolant Service System

Reactor Plant Auxiliary Systems 


\section{SHIP WORK BREAKDOWN STRUCTURE TITLES}

Main Propulsion Batteries

224 Main Propulsion Fuel Cells

Propulsion Units

Propulsion Steam Turbines

Propulsion Steam Engines

233

Propulsion Internal Combustion Engines

234

Propulsion Gas Turbines

235

Electric Propulsion

236

Self-Contained Propulsion Systems

237

238

Auxiliary Propulsion Devices

239

Secondary Propulsion (Submarines)

242

243

244

Emergency Propulsion (Submarines)

Transmission and Propulsor Systems

Propulsion Reduction Gears

Propulsion Clutches and Couplings

Propulsion Shafting

Propulsion Shaft Bearings

Propulsors

Propulsor Shrouds and Ducts

Water Jet Propulsors

Lift System Fans and Ducting

Propulsion Support Sys. (Except Fuel and Lube Oil)

Combustion Air System

Propulsion Control System

Main Steam Piping System

Condensers and Air Ejectors

Feed and Condensate System

Circulating ad Cooling Sea Water System

H.P. Steam Drain System

Uptakes (Inner Casing)

Propulsion Support Systems (Fuel and Lube Oil)

Fuel Service System

Main Propulsion Lube Oil System

Shaft Lube Oil System (Submarines)

Lube Oil Fill, Transfer, and Purification

Special Purpose Systems

Propulsion Plant Operating Fluids

Propulsion Plant Repair Parts and Special Tools

\section{Group 3 Electric Plant}

300 Electric Plant, General 


\section{SHIP WORK BREAKDOWN STRUCTURE TITLES}

301

302

303

304

305

310

311

312

313

314

320

321

322

323

324

330

331

332

340

341

342

343

390

398

399

General Arrangement-Electrical Drawings

Motors and Associated Equipment

Protective Devices

Electric Cables

Electrical Designating and Marking

Electric Power Generation

Ship Service Power Generation

Emergency Generators

Batteries and Service Facilities

Power Conversion Equipment

Power Distribution Systems

Ship Service Power Cable

Emergency Power Cable System

Casualty Power Cable System

Switchgear and Panels

Lighting System

Lighting Distribution

Lighting Fixtures

Power Generation Support Systems

SSTG Lube Oil

Diesel Support Systems

Turbine Support Systems

Special Purpose Systems

Electric Plant Operating Fluids

Electric Plant Repair Parts and Special Tools

\section{Group 4 Command and Surveillance}

Command and Surveillance, General

General Arrangement-Command and Surveillance

Security Requirements

Personnel Safety

Radio Frequency Transmission Lines

414

Antenna Requirements

Grounding and Bonding

Electromagnetic Interference Reduction (EMI)

System Test Requirements

Command and Control Systems

Data Display Group

Data Processing Group

Digital Data Switchboards

Interface Equipment 
SHIP WORK BREAKDOWN STRUCTURE TITLES

Digital Data Communications

Command and Control Analog Switchboards

Navigation Systems

Non-Electrical/Electronic Navigation Aids

Electronic Navigation Systems, Radio

Electronic Navigation Systems, Acoustical

Periscopes

Electrical Navigation Systems Inertial Navigation Systems

Navigation Control Monitoring

Interior Communications

Switchboards for I.C. Systems

Telephone Systems

Announcing Systems

Entertainment and Training Systems

Voice Tubes and Message Passing Systems

Alarm, Safety, and Warning Systems

Indicating, Order, and Metering Systems

Integrated Control Systems

Recording and Television Systems

470

Exterior Communications

Radio Systems

Underwater Systems

Visual and Audible Systems

Telemetry Systems

TTY and Facsimile Systems

Security Equipment Systems

Surveillance Systems (Surface)

Surface Search Radar

Air Search Radar (2D)

Air Search Radar (3D)

Aircraft Control Approach Radar

Identification Systems (IFF)

Multiple Mode Radar

Space Vehicle Electronic Tracking

470 Surveillance Systems (Underwater) Active Sonar

$$
\text { Passive Sonar }
$$

Multiple Mode Sonar

Classification Sonar

Bathythermograph

Countermeasures 
Active ECM (Incl Combination Active/Passive)

Passive ECM

474

Torpedo Decoys

475

Decoys (Other)

Degaussing

Mine Countermeasures

Fire Control Systems

Gun Fire Control Systems

Missile Fire Control Systems

Underwater Fire Control Systems Integrated Fire Control Systems Weapon Systems Switchboards Special Purpose Systems Electronic Test, Checkout, and Monitoring Equipment Flight Control and Instrument Landing Systems Non Combat Data Processing Systems Meteorological Systems Special Purpose Intelligence Systems Command and Surveillance Operating Fluids Command and Surv. Repair Parts and Special Tools

\section{Group 5 Auxiliary Systems} General Arrangement-Auxiliary Systems Drawings Auxiliary Machinery

$504 \quad$ Instrument and Instrument Boards

505 General Piping Requirements

506 Overflows, Air Escapes, and Sounding Tubes

$507 \quad$ Machinery and Piping Designation and Marking

508 Thermal Insulation for Piping and Machinery

509 Thermal Insulation for Vent and A/C Ducts

$510 \quad$ Climate Control

511 Compartment Heating System

512 Ventilation System

513 Machinery Space Ventilation System

514 Air Conditioning System

$515 \quad$ Air Revitalization Systems (Submarines)

516 Refrigeration System

517 Auxiliary Boilers and Other Heat Sources

520 Sea Water Systems 


\section{SHIP WORK BREAKDOWN STRUCTURE TITLES}

Firemain and Flushing (Sea Water) System

Sprinkler System

Washdown System

Auxiliary Sea Water System

Scuppers and Deck Drains

Firemain Actuated Services-Other

Plumbing Drainage

Drainage and Ballasting System

Fresh Water Systems

Distilling Plant

Cooling Water

Potable Water

Aux. Steam and Drains Within Machinery Box

Aux. Steam and Drains Outside Machinery Box

Auxiliary Fresh Water Cooling

Fuels and Lubricants, Handling and Storage

Ship Fuel and Fuel Compensating System

Aviation and General Purpose Fuels

Aviation and General Purpose Lubricating Oil

Liquid Cargo

Tank Heating

Special Fuel and Lubricants, Handling and Stowage

Air, Gas, and Misc. Fluid Systems

Compressed Air Systems

Compressed Gases

O2 N2 System

LP Blow

Fire Extinguishing Systems

Hydraulic Fluid System

Liquid Gases, Cargo

Special Piping Systems

Ship Control Systems

Steering and Diving Control Systems

Rudder

Hovering and Depth Control (Submarines)

Trim System (Submarines)

Trim and Heel Systems (Surface Ships)

Diving Planes and Stabilizing Fins (Submarines)

Strut and Foil Systems

Maneuvering Systems

Underway Replenishment Systems

Replenishment-At-Sea Systems

Ship Stores and Equip. Handling Systems 


\section{SHIP WORK BREAKDOWN STRUCTURE TITLES}

573 Cargo Handing Systems

$574 \quad$ Vertical Replenishment Systems

$580 \quad$ Mechanical Handling Systems

$581 \quad$ Anchor Handling and Stowage Systems

$582 \quad$ Mooring and Towing Systems

583 Boats, Boat Handling and Stowage Systems

584 Mechanically Operated Door, Gate, Ramp, Turntable Sys.

$585 \quad$ Elevating and Retracting Gear

$586 \quad$ Aircraft Recovery Support Systems

$587 \quad$ Aircraft Launch Support Systems

$588 \quad$ Aircraft Handling, Servicing and Stowage

589 Miscellaneous Mechanical Handling Systems

$590 \quad$ Special Purpose Systems

$591 \quad$ Scientific and Ocean Engineering Systems

Swimmer and Diver Support and Protection Systems

Environmental Pollution Control Systems

Submarine Rescue, Salvage, and Survival Systems

Towing, Launching and Handling for Underwater Sys.

Handling Sys. for Diver and Submersible Vehicles

Salvage Support Systems

Auxiliary Systems Operating Fluids

Auxiliary Systems Repair Parts and Tools

\section{Group 6 Outfit and Furnishings}

600 Outfit and Furnishings, General

601 General Arrangement-Outfit and Furn. Drawings

602 Hull Designating and Marking

603 Draft Marks

604 Locks, Keys, and Tags

605 Rodent and Vermin Proofing

610 Ship Fittings

611 Hull Fittings

612 Rails, Stanchions, and Lifelines

613 Rigging and Canvas

620 Hull Compartmentation

$621 \quad$ Non-Structural Bulkhead

622 Floor Plates and Gratings

623 Ladders

624 Non-Structural Closures

625 Airports, Fixed Portlights, and Windows

630 Preservatives and Coverings 


\section{SHIP WORK BREAKDOWN STRUCTURE TITLES}

631

632

633

634

635

636

637

638

639

640

641

642

643

644

645

650

651

652

653

654

655

656

660

661

662

663

664

665

670

671

672

673

690

698

699

Painting

Zinc Coating

Cathodic Protection

Deck Covering

Hull Insulation

Hull Damping

Sheathing

Refrigerated Spaces

Radiation Shielding

Living Spaces

Officer Berthing and Messing Spaces

Noncommissioned Officer Berthing and Messing Spaces

Enlisted Personnel Berthing and Messing Spaces

Sanitary Spaces and Fixtures

Leisure and Community Spaces

Service Spaces

Commissary Spaces

Medical Spaces

Dental Spaces

Utility Spaces

Laundry Spaces

Trash Disposal Spaces

Working Spaces

Offices

Machinery Control Centers Furnishings

Electronics Control Centers Furnishings

Damage Control Stations

Workshops, Labs, Test Areas (Incl Portable Tools, Equip)

Stowage Spaces

Lockers and Special Stowage

Storerooms and Issue Rooms

Cargo Stowage

Special Purpose Systems

Outfit and Furnishings Operating Fluids

Outfit and Furnish. Repair Parts and Special Tools

\section{Group 7 Armament}

700 Armament, General

701 General Arrangement-Weaponry Systems

702 Armament Installations

703 Weapons Handling and Stowage, General 


\section{SHIP WORK BREAKDOWN STRUCTURE TITLES}

710

711

712

713

720

721

722

723

724

725

726

727

728

729

730

731

732

733

740

741

742

743

750

751

752

753

754

760

761

762

763

770

772

773

780

782

783

790

792

793

797

798

799
Guns and Ammunition

Guns

Ammunition Handling

Ammunition Stowage

Missiles and Rockets

Launching Devices (Missiles and Rockets)

Missile, Rocket, and Guidance Capsule Handling Sys.

Missile and Rocket Stowage

Missile Hydraulics

Missile Gas

Missile Compensating

Missile Launcher Control

Missile Heating, Cooling, Temperature Control

Missile Monitoring, Test and Alignment

Mines

Mine Launching Devices

Mine Handling

Mine Stowage

Depth Charges

Depth Charge Launching Devices

Depth Charge Handling

Depth Charge Stowage

Torpedoes

Torpedo Tubes

Torpedo Handling

Torpedo Stowage

Submarine Torpedo Ejection

Small Arms and Pyrotechnics

Small Arms and Pyrotechnic Launching Devices

Small Arms and Pyrotechnic Handling

Small Arms and Pyrotechnic Stowage

Cargo Munitions

Cargo Munitions Handling

Cargo Munitions Stowage

Aircraft Related Weapons

Aircraft Related Weapons Handling

Aircraft Related Weapons Stowage

Special Purpose Systems

Special Weapons Handling

Special Weapons Stowage

Misc. Ordnance Spaces

Armament Operating Fluids

Armament Repair Parts and Special Tools 
Group 8 Integration/Engineering (Shipbuilder Response)

800

801

802

803

804

806

810

811

812

813

820

830

831

832

833

834

835

836

837

838

839

840

841

842

843

844

Integration/Engineering (Shipbuilder Response)

Shipbuilders Information Drawings

Contract Drawings

Standard Drawings

Type Drawings

Study Drawings

Production Engineering

Configuration Management

Change Proposals, Scoping and Shipchecking

Planning and Production Control

Special Drawings for Nuclear Propulsion Systems

Design Support

Construction Drawings

Specifications

Weight Engineering

Computer Programs

Engineering Calculations

Models and Mockups

Photographs

Design/Engineering Liaison

Lofting

Quality Assurance

Tests and Inspection, Criteria, and Procedures

Trials Agenda Preparation, Data Collection ad Anal.

Inclining Experiment and Trim Dive

Combat Systems Checkout Criteria and Procedures

Certification Standards

Integrated Logistic Support Engineering

Maintenance

Support and Test Equipment

Supply Support

Transportation

Engineering Drawings and Specifications

Technical Manuals and Other Data

Facilities

Personnel and Training

Training Equipment

Special Purpose Items

Safety 


\section{SHIP WORK BREAKDOWN STRUCTURE TITLES}

892

893

894

895

896

897

Human Factors

Standardization

Value Engineering

Reliability and Maintainability

Data Management

Project Management

\section{Group 9 Ship Assembly and Support Services}

Ship Assembly and Support Services

901 Thru 979 Reserved for Ident. of Assemblies

Contractual and Production Support Service

Insurance

Trials

Delivery

Open and Inspect (Conversions Only)

Fire and Flooding Protection

Tests and Inspection

Weighing and Recording

Contract Data Requirements (Administration)

Fitting-Out

Construction Support

Staging, Scaffolding, and Cribbing

Temporary Utilities and Services

Material Handling and Removal

Cleaning Services

Molds and Templates, Jigs, Fixtures, and Spec. Tools

Launching

Drydocking 
Appendix C

Organizations and Acronyms 


\section{ORGANIZATIONS AND ACRONYMS IN DATABASE}

\begin{tabular}{|c|c|}
\hline TORC & 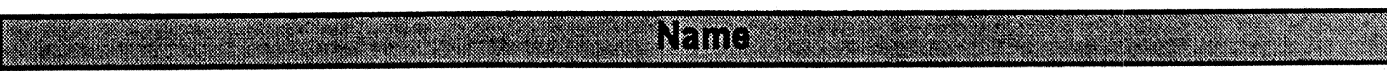 \\
\hline A.G.A. & American Gas Association \\
\hline A.P.I. & American Paper Institute \\
\hline$\overline{A A}$ & Aluminum Association \\
\hline$\overline{A A M A}$ & American Architectural Manufacturers Association \\
\hline$\overline{A B M A}$ & American Bearing Manufacturers Association \\
\hline ABMA. & American Boiler Manufacturers Association \\
\hline$\overline{A B S}$ & American Bureau Of Shipping Rules for Building and Classing Steel Vessels \\
\hline ABS01 & ABS Rules for Nondestructive Inspection of Hull Welds \\
\hline $\mathrm{ABSO2}$ & ABS Requirements for Approved Welding Consumables \\
\hline $\mathrm{ABSO3}$ & ABS Rules for Building and Classing Mobile Offshore Drilling Units \\
\hline ABS04 & ABS Rules for Building and Classing Steel Barges \\
\hline ABS05 & ABS Bulk Carriers for Service on the Great Lakes \\
\hline ABS06 & ABS Rules for Steel Vessels on Rivers \\
\hline ABS07 & ABS Guide for Inert Gas Systems \\
\hline ABSO8 & ABS Rules for Certification of Cargo Containers \\
\hline ABSO9 & ABS Manual for Making Bronze Propeller Repairs \\
\hline ABS10 & ABS Guide for Repair and Cladding of Shafts \\
\hline ABS11 & ABS Guide for Burning Crude Oil \& Slops in Main \& Auxiliary Boilers \\
\hline ABS12 & ABS Rules for Steel Floating Drydocks \\
\hline ABS13 & ABS Guide for Underwater Inspection in Lieu of Drydocking Survey \\
\hline ABS14 & ABS Guide for Construction of Shipboard Elevators \\
\hline ABS15 & ABS Requirements for Certification of Cargo Gear on Merchant Vessels \\
\hline ABS16 & ABS Requirements for Certification of Self-Unloading Cargo Gear on Great Lakes Vsls \\
\hline ABS17 & ABS Requirements for Single Point Moorings \\
\hline ABS18 & ABS Rules for Aluminum Vessels \\
\hline ABS19 & ABS Rules for Classification of Nuclear Ships \\
\hline ABYC & American Boat And Yacht Council \\
\hline ACCA & Air Conditioning Contractors Of America \\
\hline AEIC & Association Of Edison Illuminating Companies \\
\hline AES & Audio Engineering Society \\
\hline AFNOR & Association Francaise De Normalisation \\
\hline AFS & American Foundrymen's Society \\
\hline AGMA & American Gear Manufacturers Association \\
\hline $\mathrm{AICHE}$ & American Institute Of Chemical Engineers \\
\hline AlHA & American Industrial Hygiene Association \\
\hline AISC & American Institute Of Steel Construction \\
\hline AISG & American Insurance Services Group Inc. \\
\hline AISI & American Iron And Steel Institute \\
\hline AlTC & American Institute Of Timber Construction \\
\hline ALCA & American Leather Chemists Association \\
\hline AMCA & Air Movement And Control Association \\
\hline ANSI & American National Standards Institute \\
\hline ANSI/A.G.A. & American National Standards Institute \\
\hline ANSI/ABMA & American National Standards Institute \\
\hline ANSI/ABYC & American National Standards Institute \\
\hline
\end{tabular}


ORGANIZATIONS AND ACRONYMS IN DATABASE

\begin{tabular}{|c|c|}
\hline ANSI/AGMA & American National Standards Institute \\
\hline ANSI/API & American National Standards Institute \\
\hline ANSI/ARI & American National Standards Institute \\
\hline ANSI/ASHRAE & American National Standards Institute \\
\hline ANSIIASME & American National Standards Institute \\
\hline ANSI/ASSE & American National Standards Institute \\
\hline ANSIIASSE. & American National Standards Institute \\
\hline ANSIIASTM & American National Standards Institute \\
\hline ANSI/AWS & American National Standards Institute \\
\hline ANSI/AWWA & American National Standards Institute \\
\hline ANSI/CEMA & American National Standards Institute \\
\hline ANSI/DISA & American National Standards Institute \\
\hline ANSI/EIA & American National Standards Institute \\
\hline ANSI/HI. & American National Standards Institute \\
\hline ANSI/IAPMO & American National Standards Institute \\
\hline ANSI/IEEE & American National Standards Institute \\
\hline ANSI/ISA & American National Standards Institute \\
\hline ANSI/NACE & American National Standards Institute \\
\hline ANSI/NEMA & American National Standards Institute \\
\hline ANSI/NFP(A) & American National Standards Institute \\
\hline ANSI/NFPA & American National Standards Institute \\
\hline ANSI/NSF & American National Standards Institute \\
\hline ANSI/SAE & American National Standards Institute \\
\hline ANSI/SDI & American National Standards Institute \\
\hline ANSI/SIA & American National Standards Institute \\
\hline ANSI/UL & American National Standards Institute \\
\hline APA & The Engineered Wood Association \\
\hline $\mathrm{API}$ & American Petroleum Institute \\
\hline ARI & Air-Conditioning And Refrigeration Institute \\
\hline ARM & Asphalt Roofing Manufacturers \\
\hline ASCE & American Society Of Civil Engineers \\
\hline ASHRAE & American Society Of Heating, Refrigeration, And Air-Conditioning Engineers \\
\hline ASME & American Society Of Mechanical Engineers \\
\hline ASNT & American Society For Nondestructive Testing \\
\hline ASSE. & American Society Of Safety Engineers \\
\hline ASTM & American Society For Testing And Materials \\
\hline ATA. & American Trucking Association \\
\hline AVS & American Vacuum Society \\
\hline AWI & Architectural Woodwork Institute \\
\hline AWPA & American Wood-Preservers' Association \\
\hline AWS & American Welding Society \\
\hline AWWA & American Water Works Association \\
\hline $\mathrm{BIA}$ & Brick Institute Of America \\
\hline BSI & British Standards Institution \\
\hline Bundesam & Bundesam \\
\hline BV & Bureau Vistas \\
\hline
\end{tabular}




\begin{tabular}{|c|c|}
\hline CAA & Civil Aviation Authority \\
\hline CCTI & Composite Can And Tube Institute \\
\hline CDA & Copper Development Association \\
\hline CECC & Cenelec Electronic Components Committee \\
\hline CED & Civil Engineering Data \\
\hline CEMA & Conveyor Equipment Manufacturers Association \\
\hline CEN & European Committee For Standardization \\
\hline CENELEC & Cenelec Electronic Components Committee \\
\hline CEPT & Conference Europeenne Des Administrations Des Postes \\
\hline CFFA & Chemical Fabrics And Film Association \\
\hline CGA & Compressed Gas Association \\
\hline CGNVIC & US Coast Guard Navigation And Vessel Inspection Circular \\
\hline CGSB & Canadian General Standards Board \\
\hline $\mathrm{CHI}$ & Chlorine Institute \\
\hline $\mathrm{Cl}$ & Cordage Institute \\
\hline CIMA & Construction Industry Manufacturers Association \\
\hline CINS & Composites Institute \\
\hline CMAA & Crane Manufacturers Association Of America \\
\hline CNS & Chinese National Standards \\
\hline CPB & Contractors Pump Bureau \\
\hline CPPA & Canadian Pulp And Paper Association \\
\hline CSA & Canadian Standards Association \\
\hline CSI & Construction Specifications Institute \\
\hline CSMA & Chemical Specialties Manufacturers Association \\
\hline CTI & Cooling Tower Institute \\
\hline DEF S & British Defense Standards \\
\hline $\mathrm{DFI}$ & Deep Foundations Institute \\
\hline $\mathrm{DHI}$ & Door And Hardware Institute \\
\hline DIN & Deutsches Institut Fur Normung \\
\hline DIN ENGLISH & Deutsches Institut Fur Normung (English) \\
\hline DISA & Data Interchange Standards Association \\
\hline DNV & Det Norske Veritas \\
\hline DNV FOI & Det Norske Veritas \\
\hline DNV HSLC & Det Norske Veritas (High Speed Light Craft) \\
\hline DNV MOU & Det Norske Veritas (Mobile Offshore Units) \\
\hline DOD & Department Of Defense \\
\hline DOL & Department Of Labor \\
\hline$E C$ & European Council \\
\hline$E \mid A$ & Electronic Industries Association \\
\hline EPA & Environmental Protection Agency \\
\hline ETSI & European Telecommunications Standards Institute \\
\hline $\mathrm{FCl}$ & Fluid Controls Institute \\
\hline FED-SPEC & Federal Specification \\
\hline FMERC & Factory Mutual Engineering And Research Corp. \\
\hline GL & Germanischer Lloyd \\
\hline GMA & Grocery Manufacturers Of America \\
\hline
\end{tabular}


ORGANIZATIONS AND ACRONYMS IN DATABASE

\begin{tabular}{|c|c|}
\hline GPA & Gas Processors Association \\
\hline $\mathrm{HEl}$ & Heat Exchange Institute \\
\hline $\mathrm{HI}$ & Hydronics Institute \\
\hline HI. & Hydraulic Institute \\
\hline IAEA & International Atomic Energy Agency \\
\hline IAPMO & International Association Of Plumbing And Mechanical Officials \\
\hline ICAC & Institute Of Clean Air Companies \\
\hline ICAO & International Civil Aviation Organization \\
\hline $\mathrm{ICl}$ & Investment Casting Institute \\
\hline IEC & International Electrotechnical Commission \\
\hline IECQ & IEC Quality Assessment System \\
\hline IEEE & Institute Of Electric And Electronics Engineers \\
\hline IESNA & Illuminating Engineering Society Of North America \\
\hline IFAI & Industrial Fabrics Association International \\
\hline $\mid \mathrm{FI}$ & Industrial Fasteners Institute \\
\hline IIAR & International Institute Of Ammonia Refrigeration \\
\hline IMCO & Intergovernmental Maritime Consultive Organization \\
\hline IPC & Institute For Interconnecting And Packaging Electronic Circuits \\
\hline IPCEA & Insulated Cable Engineers Association \\
\hline IRI & Industrial Risk Insurers \\
\hline ISA & International Society For Measurement And Control \\
\hline ISDSI & Insulated Steel Door Systems Institute \\
\hline ISO & International Organization For Standardization \\
\hline ISS & Iron And Steel Society \\
\hline ITU-R & International Telecommunications Union \\
\hline ITU-T & International Telecommunications Union \\
\hline JIC & Joint Industrial Council \\
\hline JIS & Japanese Industrial Standards \\
\hline JTC1 & Joint Technical Committee \\
\hline KS & Korean Standards Association \\
\hline LIA & Lead Industries Association \\
\hline Lloyds & Lloyd's Register Of Shipping \\
\hline MARAD & Maritime Administration \\
\hline MASS & MARAD Standards Specification \\
\hline MASSD & MARAD Standards Specification (Diesel) \\
\hline $\mathrm{MHI}$ & Material Handling Institute \\
\hline MICA & Midwest Insulation Contractors Association \\
\hline MOD UK & British Defense Standards \\
\hline MPIF & Metal Powder Industries Federation \\
\hline MSS & Manufacturers Standardization Society Of The Valve And Fittings Industry \\
\hline NAAMM & National Association Of Architectural Metal Manufacturers \\
\hline NACE & NACE International \\
\hline NACM & National Association Of Chain Manufactures \\
\hline NAIMA & North American Insulation Manufacturers Association \\
\hline NAPCA & National Association Of Pipe Coating Applicators \\
\hline NAPHCC & National Association Of Plumbing-Heating-Cooling Contractors \\
\hline
\end{tabular}




\begin{tabular}{|c|c|}
\hline NATO & North American Treaty Organization \\
\hline NBBP & National Board Of Boiler And Pressure Vessel Inspectors \\
\hline NCRP & National Council On Radiation Protection And Measurements \\
\hline NEBB & National Environmental Balancing Bureau \\
\hline NEMA & National Electrical Manufacturers Association \\
\hline NFP(A) & National Fluid Power Association \\
\hline NFPA & National Fire Protection Association \\
\hline NIST & National Institute Of Standards And Technology \\
\hline NLA & National Lime Association \\
\hline $\mathrm{NNI}$ & Netherlands Standards Institute \\
\hline NPGA & National Propane Gas Association \\
\hline NSC & National Safety Council \\
\hline NSF & NSF International \\
\hline NTIAC & Nondestructive Testing Information Analysis Center \\
\hline NWWDA & National Wood Window And Door Association \\
\hline OCIMF & Oil Companies International Marine Forum \\
\hline $\mathrm{PCC}$ & Panama Canal Company \\
\hline PDCA & Painting And Decorating Contractors Of America \\
\hline $\mathrm{PFI}$ & Pipe Fabrication Institute \\
\hline PHILIPPINE & Philippine National Standards \\
\hline PLASTEC & Plastics Technical Evaluation Center \\
\hline $\mathrm{PPI}$ & Plastics Pipe Institute \\
\hline PTI & Post-Tensioning Institute \\
\hline RAC & Reliability Analysis Center \\
\hline RIA & Robotic Industries Association \\
\hline RMA & Rubber Manufacturers Association \\
\hline RWMA & Resistance Welder Manufacturers Association \\
\hline SAA & Standards Association Of Australia \\
\hline SACMA & Suppliers Of Advanced Composite Materials Association \\
\hline $\mathrm{SAE}$ & Society Of Automotive Engineers \\
\hline SASO & Saudi Arabian Standards Organization \\
\hline SCA & Suez Canal Authority \\
\hline SDI & Steel Door Institute \\
\hline SDI. & Steel Deck Institute \\
\hline SEMI & Semiconductor Equipment And Materials International \\
\hline SFSA & Steel Founders Society Of America \\
\hline SIA & Scaffold Industry Association \\
\hline SIRIM & Standards And Industrial Research Institute Of Malaysia \\
\hline SISIR & Singapore Institute Of Standards And Industrial Research \\
\hline SJI & Steel Joist Institute \\
\hline SMACNA & Sheet Metal And Air Conditioning Contractors National Association \\
\hline SNAME & Society Of Naval Architects And Marine Engineers \\
\hline SNZ & Standards New Zealand \\
\hline SOLAS & Safety Of Life At Sea \\
\hline SPIB & Southern Pine Inspection Bureau \\
\hline SPII & Society Of The Plastics Industry \\
\hline
\end{tabular}


ORGANIZATIONS AND ACRONYMS IN DATABASE

\begin{tabular}{|l|l|}
\hline SSFI & Scaffolding And Shoring And Forming Institute \\
\hline SSPC & Steel Structures Painting Council \\
\hline SSPMA & Sump And Sewage Pump Manufacturers Association \\
\hline STI & Steel Tank Institute \\
\hline TAPPI & TAPPI \\
\hline TEMA & Tubular Exchange Manufacturers Association \\
\hline TTMA & Truck Trailer Manufacturers Association \\
\hline UBPPA & Uni-Bell PVC Pipe Association \\
\hline UL & Underwriters Laboratories \\
\hline ULC & Underwriters Laboratories Of Canada \\
\hline USCG & United States Coast Guard \\
\hline USDA & United States Department Of Agriculture \\
\hline USN & United States Navy \\
\hline USPHS & United States Public Health Service \\
\hline VDE & Verband Deutscher Elektroniker \\
\hline VDI & Verin Deutscher Ingenieure \\
\hline WEF & Water Environment Federation \\
\hline WRI & Wire Reinforcement Institute \\
\hline
\end{tabular}




\section{Appendix D}

\section{Sample Search Printouts}

Search under Organization for ASTM, last 3 of 73 pages...........Appendix D-1

Search under SWBS 220 (Energy Generating System) Appendix D-4 


\section{Standards Database Search Results}

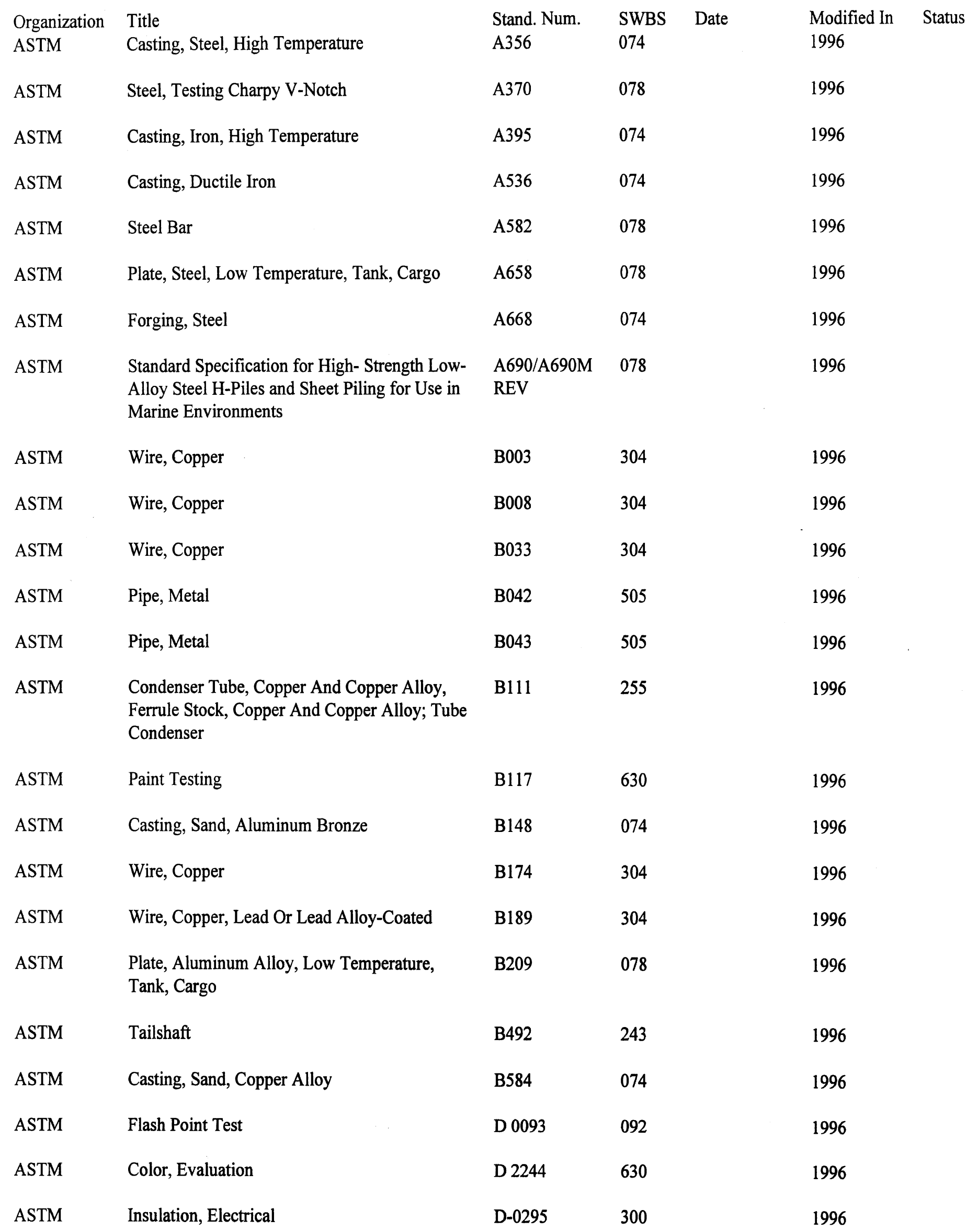




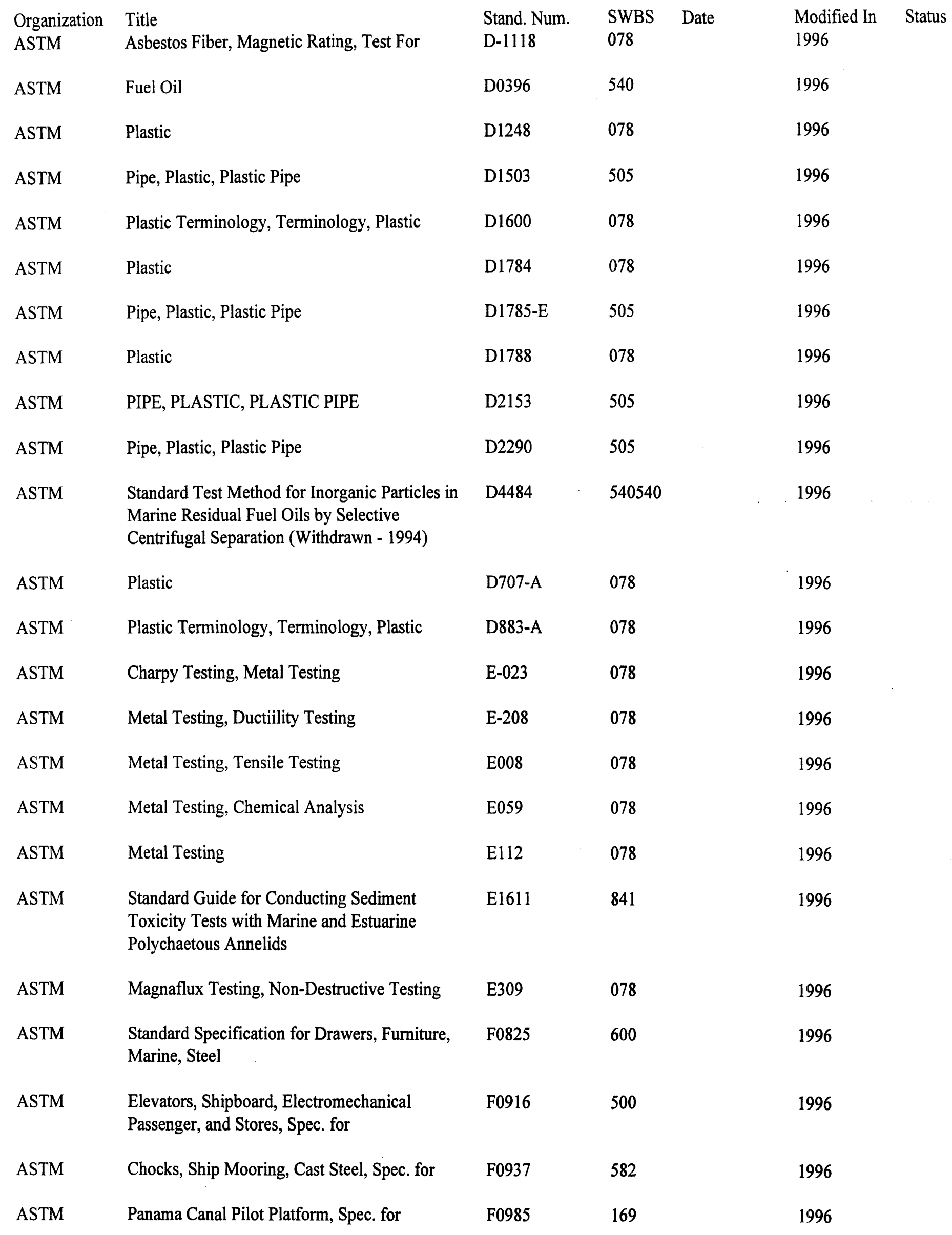




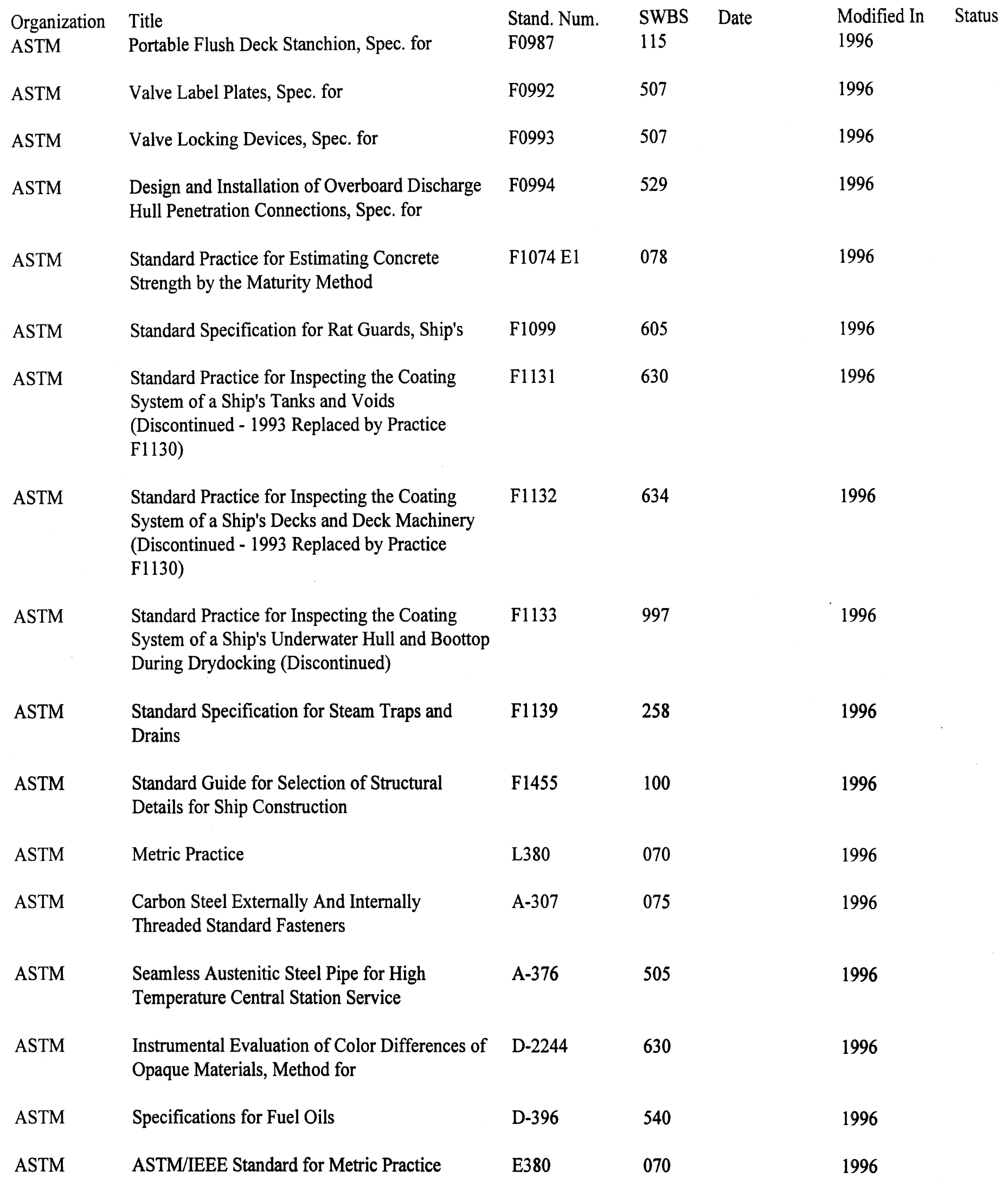




\section{Standards Database Search Results}

Stand. Num. Title

BS 1113

1989 Amd 4 Design and Manufacture of Water-Tube Steam Generating Plant (Including Superheaters, Reheaters and Steel Tube Economizers) (Q) (AMD 6717) May 31, 1991

BS 1113

1992 Design and Manufacture of Water-Tube Steam Generating Plant (Including Superheaters, Reheaters and Steel Tube Economizers) (Q)

BS 1113

1992 Amd 1 Design and Manufacture of Water-Tube Steam Generating Plant (Including Superheaters, Reheaters and Steel Tube Economizers) (AMD 7167) June 15, $1992(\mathrm{Q})$

BS 1113

1992 Amd 2 Design and Manufacture of Water-Tube Steam Generating Plant (Including Superheaters, Reheaters and Steel Tube Economizers) (AMD 8178) June 15, 1994 (Q)

BS 1113: ENQ 1986 Design and Manufacture of Water-Tube Steam CASE 1 Generating Plant (Including Superheaters, Reheaters and Steel Tube Economizers) Enquiry Case 1: Eddy Current Testing in Lieu of Hydraulic Testing

BS 1113: ENQ 1995 Design and Manufacture of Water-Tube Steam CASE 10 Generating Plant (Including Superheaters, Reheaters and Steel Tube Economizers) Enquiry Case 10: Use of Steel $91(\mathrm{Q})$

BS 1113: ENQ 1990 Design and Manufacture of Water-Tube Steam CASE 2 Generating Plant (Including Superheaters, Reheaters and Steel Tube Economizers) Enquiry Case 2: Use of ASTM A105, A106, A182, A234, A335, and A312 Materials (Q)

BS 1113: ENQ 1987 Design and Manufacture of Water-Tube Steam CASE 3 Generating Plant (Including Superheaters, Reheaters and Steel Tube Economizers) Enquiry Case 3: Local Loads

BS 1113: ENQ 1989 Design and Manufacture of Water-Tube Steam CASE 4 Generating Plant (Including Superheaters, Reheaters and Steel Tube Economizers) Enquiry Case 4:

Methods for Manual Examination of Fusion Welds in Ferritic Steels

BS 1113: ENQ 1988 Design and Manufacture of Water-Tube Steam CASE 5 Generating Plant (Including Superheaters, Reheaters

\author{
Or
}

BSI

SWBS Date

Modified Status

In

$220 \quad 1989-00-00$

1997

BSI

1992-00-00

1997

BSI

$220 \quad 1901-00-00$

1997

BSI

220

1902-00-00

1997

BSI

220

1986-00-00

1997

BSI

1995-00-00

1997

BSI

220

1990-00-00

1997

BSI

1987-00-00

1997

BSI

1989-00-00

1997

BSI

220

1988-00-00

1997

and Steel Tube Economizers) Enquiry Case 5: British Standard Forging and Pipe Materials 
Stand. Num. Title

BS 1113: ENQ 1990 Design and Manufacture of Water-Tube Steam CASE 6 Generating Plant (Including Superheaters, Reheaters and Steel Tube Economizers) Enquiry Case 6: Use of BS 3604591 Material

BS 1113: ENQ 1992 Design and Manufacture of Water-Tube Steam CASE 7

Generating Plant (Including Superheaters, Reheaters and Steel Tube Economizers) Enquiry Case 7: Use of Butt Welds in Tubes for Manufacture of Coils for Coil Type Boilers/ Superheaters (Q)

BS 1113: ENQ 1992 Design and Manufacture of Water-Tube Steam CASE 8 Generating Plant (Including Superheaters, Reheaters and Steel Tube Economizers) Enquiry Case 8:

Ultrasonic Acceptance Criteria (Q)

BS 1113: ENQ CASE 9

1993 Design and Manufacture of Water-Tube Steam Generating Plant (Including Superheaters, Reheaters and Steel Tube Economizers) Enquiry Case 9: Welding Procedure Specification, Welding Procedure Approval and Welder Approval (Q)

BS 1113: ENQ 1994 Design and Manufacture of Water-Tube Steam CASE INTRO Generating Plant (Including Superheaters, Reheaters and Steel Tube Economizers) Enquiry CasesIntroduction (Q)

BS 1374

(WITHDRAWN) 1972 Recommendations on the Use of British Standard Log Sheets for Steam and Hot Water Boiler Plants

BS 1846: $\quad 1968$ Glossary of Terms Relating to Solid Fuel PART 2 Burning Equipment Part 2: Industrial Water Heating and Steam Raising Installations

BS 28851974 Amd 1 Code for Acceptance Tests on Stationary Steam Generators of the Power Station Type

DI-L-2183 Engine - Module Status Report (Superseded By DiIlss-80223)

DI-MISC- $\quad$ Heat Balance Calculations And Flow Diagrams For 80853 Main Propulsion Plant Systems (Steam Driven Ships)

J 0620

Flywheels for Industrial Engines Used with Industrial Power Take-Offs Equipped with Driving-Ring Type Overcenter Clutches and Engine-Mounted Marine Gears and Single Bearing Engine

MIL-G-17934 Generator Set, Diesel Engine, Ship Propulsion, 1335 Bhp Continuous Rating

MIL-T$17188 \mathrm{D}$ Tube, Carbon Steel, Electric Resistance Welded, Marine Boiler (Use Astm A1780002)
Date

Modified Status

BSI

220

1990-00-00

BSI

220

1992-00-00

1997

BSI

220

1992-00-00

1997

BSI

220

1993-00-00

1997

BSI

1994-00-00

1997

BSI

220

1972-00-00

1997

BSI

220

1968-00-00

1997

BSI

220

1974-00-00

1997

DOD

220

$2 / 15 / 83$

DOD

$6 / 14 / 89$

ANSI

220

1996

DOD

220

1996

H

DOD

220

1996

CANC

NOTICE 1 